\title{
A.8 Unspecified collection Ms. and Asha Archives, Kathmandu, Ms. $2507^{13}$
}

\author{
A Nepalese paper manuscript of 265 leaves from $1851 \mathrm{CE}$ (NS 971). ${ }^{14} \mathrm{On}$ folios $262 \mathrm{v}-$ \\ $265 \mathrm{v}$ there is a numbered list of 125 dhāranīis. ${ }^{15}$
}

Note that ms. 2507 kept at the Asha Archives, Kathmandu and dated to 1881 CE (NS $1001)$ is closely related to this piece ${ }^{16}$

1. Vajrasattvakāyasya tathāgatavyāptaśata $3 \mathrm{r} / 2 \mathrm{v}^{17}$

2. Māyājālāt ṣoḍaśasāhasrikān mahāyogatantrāntaḥpātisamādhijālapațalād bhagavattathāgataśākyamunibhāṣitā bhagavato mañjuśriijñānasattvasya paramārthā-nāmasaṃgīti 14v/11r [57]

3. Aparimitā-nāma-dhāraṇi mahāyānasūtra 23r/17v [47]

13 Faximiles and a Devanāgarī transcript are published in Bhosekar 2017. Titles given with improvements and minor standardizations. Corresponding text numbers in Cambridge Ms. Add. 1326 are given in square brackets (there is a chance of inconsistencies in the case of texts which appear by the same title more than once).

14 The dated colophon on folio 265 is given with improvements and minor standardizations here: iti dhāraṇīsaṃgrahanāmasarvaśāstra parisamāptạ̣ | śubhasaṃvat 971 jyeșthavadiḍhacoyasiddhayakādim | dānapati bubāhālayāvajrācārya śrī bhākṣamacākṣa sabhāryā devamayakșa saputra śrī dverāja dvitīyaputra śrī munirājakṣa | tṛtīya putra śrī dharmarāja | putrī jiothakuṃthatejalasamohavaṃcākātayākșaro | śubham | dānapatiyā iha loke sukhasaṃpatti paraloke sukhāvatīm | śubham bubāhālamūla?vārayā śrī dhīrjacoyāviyā. Note that in Bhosekar 2017 folio $2 \mathrm{r}$ is reproduced twice with $2 \mathrm{v}$ missing, 64 is reproduced twice with 63 missing, $104 \mathrm{r}$ is reproduced twice with $103 \mathrm{v}$ missing, $114 \mathrm{r}$ is reproduced twice with $113 \mathrm{v}$ missing, $118 \mathrm{v}$ is blank, $132 \mathrm{v}$ is missing and $148 \mathrm{v}$ is reproduced twice. A few folios from seemingly other manuscripts are reproduced after $265 \mathrm{v}$.

15 Note that this list that looks like a table of contents only at places corresponds to the sequence of texts in the actual manuscript. At the end of the list numbers 126 and 127 are also added but it is the final colophon which starts here.

16 The 178 folios contain the same 106 dhāranīs. The dated colophon on folios $177 \mathrm{r}-178 \mathrm{r}$ is given with improvements and minor standardizations here: iti śrī-dhāraṇīsaṃgrahamahāpurāna-sarvaśāstropahita-nāma-dhāranīpañcaviṃśataka samāptaḥ | śubham | śreyo 'stu saṃvat | 1001 sti āsurakamāsyakṛṣnapakṣacaturthīyāṃ mahāpuṣye tithau kṛttikānakṣatre raḥvyale pātayoge jathākarṇamuhūrte maṅgavārasaraḥ kanyārāšigate savitaraḥ vṛsarāśigate śrīsūrya | thva khuhnusidhayakādvinajñāna likhitaṃ vi??mahāvihārayā vajrācāryaśrīkuladhaṃnathavatathamanavāyājula | dānapatiśrīkulavinaḥ śrīkulagītị̣ śrīkuladhanakāyacā śrīcakravilamāma śrîsubhala?iḥbhota śrīdhanathakuhbhota śrībhathakuhstridhanathakam | jalabhā?sayā dharmacitta-utpattijayāśạ̣ dhāraṇīsaṃgrahapustaka deyakośasaṃpūrṇayo rākṣala | the rest is in vernacular.

17 Folio numbers of Asha Ms. 2507 are indicated as second.

ว Open Access. (C) 2021 Gergely Hidas, published by De Gruyter. (c) BY-NC-ND This work is licensed under the Creative Commons Attribution-NonCommercial-NoDerivatives 4.0 International License. https://doi.org/10.1515/9783110713367-011 
4. Saptaśatikā-prajñāpāramitā 60r/43r [163]

5. Pañcaviṃśatikā-prajñāpāramitā-nāma-dhāraṇī 62r/44r [101]

6. Svalpākṣarā-bhagavatī-prajñāpāramitā-nāma-dhāraṇī 64v/46r [164]

7. Ardhaśatikā-prajñāpāramitā $67 v / 48 r$

8. Sugatāvadāna-saptabuddha-stuti 68v/49r

9. Mūlavidyāmantrasiddhi-dhāraṇī 69r/49v [1]

10. Vairocana-nāma-dhāraṇi 69r/49v [3]

11. Akṣobhya-nāma-dhāraṇī 69v/49v [4]

12. Ratnasambhava-nāma-dhāraṇī 69v/49v [5]

13. Amitābhasya-nāma-dhāraṇī 69v/49v [6]

14. Amoghasiddhi-nāma-dhāraṇī 69v/49v [7]

15. Amṛtabhakṣā-nāma-dhāraṇī 69v/50r [117]

16. Arapacanamañjuśrīsādhana-nāma-dhāraṇī 70r/50r [123]

17. Suvarṇaprabhāyāṃ kuladevatā-stuti 71r/50v

18. Maitreyapratijñā-nāma-sūtra 71r/51r [87]

19. Maitreya-nāma-dhāraṇī 71v/51r [124]

20. Amoghapāśa-nāma-hṛdaya-mahāyānasūtra-nāma-dhāraṇī 80v/58v [63]

21. Khasarpa-nāma-dhāraṇī 80v/58v [122]

22. Abhayaṃkarī-nāma-dhāraṇī 81r/59r [72]

23. Sahasrabhujalokeśvarasya-nāma-dhāraṇī 81v/59v [66]

24. Simhanādalokeśvara-nāma-dhāraṇī 81v/59v [64]

25. Mokṣaprada-nāma-dhāraṇi 82r/59v [71]

26. Avalokiteśvarasya siddhinikā-nāma-dhāraṇī 82r/59v [65, 116]

27. Ṣaḍakṣarī-mahāvidyā-nāma-dhāraṇī 83v/60v [69, 139]

28. Avalokiteśvarasya nīlakaṇthha-hṛdaya 84v/61v [67]

29. Padmahasta-dhāraṇī 85r/61v [17]

30. Sahasrāvartā-nāma-dhāraṇī 85r/62r [68]

31. Prathamākṣarasaptamiśraṇasamyuktaṣaḍakṣara-stava 86v/62v

32. Avalokiteśvarasya jamarāja-stuti 87v/63v

33. Avalokiteśvarasya umāmaheśvarakṛta-stuti 88r/64r

34. Bhadracari-mahāpraṇidhānaratnarāja 93v/67v [70]

35. Sarvajñajinaratnadhātukaraṇụaka-nāma bhagavanta āryālokiteśvarasya așțottaraśata-nāma-mahāyānasūtra 95v/69v [140]

36. Sarvadurgatipariśodhanarājasya tathāgatasyārhatạ̣ samyaksambuddhasya kalpaika 104v/75r [48]

37. Gaṇḍavyūha-nāma-dhāraṇī 104v/75r [9]

38. Samādhirāja-nāma-dhāraṇī 104v/75v [11]

39. Lañkāvatārapathiphala-nāma-dhāraṇī 104v/75v [12]

40. Așțamahābhayapungala-nāma-dhārạ̣ī 105r/75v

41. Karṇajāpā-nāma-dhāraṇī 105r/75v [40] 
42. Sarvapāpadahana-nāma-dhāraṇī 105v/76r [41]

43. Vajrasarasvatī-nāma-dhāraṇī 105v/76r [93]

44. Puṇyavivardhanī-nāma-dhāraṇi 105v/76r [52, 138]

45. Saddharmapuṇụarīka-nāma-dhāraṇī 106r/76v [13]

46. Gāthādvaya-nāma-dhāraṇī 106v/76v [43]

47. Amritā-nāma-dhāraṇī 107r/77r

48. Sugatavajra-nāma-dhāraṇī 107r/77r

49. Bhaiṣajyarāja-nāma-dhāraṇī 107r/77r [38]

50. Śākyamuni-nāma-dhārạ̣ī 107r/77r [32]

51. Cundā-nāma-dhāraṇī 107v/77r [75, 110]

52. Dhvajāgrakeyūra-nāma-dhāraṇī 108v/78r [90]

53. Mahāsamvvara-hṛdaya 110r/79r [173?]

54. Caṇdamahāroṣaṇasamādhi-hṛdaya 111r/79v [172?]

55. Herukasya sarvarogapraśamanī-nāma-dhāraṇī 111r/80r

56. Mahāmāyāvajravārāhī-nāma-dhāraṇī 112r/80v [105]

57. Abhimantraphaladā-siddhidāyanī vajrayoginīnairātmāguhyeśvarī-mantranāma-dhāraṇī 114v/82r

58. Tārā-nāma-dhāraṇī 114v/82r [?]

59. Yogāmbarasya karmarāja-nāma-dhārạ̣ī 115r/82v [120]

60. Ugratārā-nāma-dhāraṇī 115v/82v [127]

61. Jāṅgulī-hṛdaya-nāma-dhāraṇī 115v/83r

62. Daśakrodha-nāma-dhāraṇī 116r/83r [114, 128]

63. Ușṇīṣacakravartī-nāma-dhāraṇī 116r/83r [50]

64. Lokātīta-stava-nāma-stotra 117v/84v [176]

65. Tārābhaț̣ārikāyā nāmāșțottaraśata-buddhabhāṣita 123r/87v

66. Tārābhatțārikāyāh sragdharā-stotra 128r/91r

67. Ekajațā-nāma-dhāraṇī 135v/96r [113]

68. Svayambhūpurāne caityabhațāārakoddeśa-mahāprabhāvavarṇano -nāmāșțama-pariccheda 153r/109r

69. Vasudhārāvratapūrvamartyamaṇḍalāgatakathā 164v/116v

70. Vasudhārāyā nāmāșțottaraśata-buddhabhāṣita 166r/117v [97]

71. Vajravidāriṇīhṛ̂aya-mūlamantra-dhārạ̣ī 168r/119r [98]

72. Gaṇapati-hṛdayā-nāma-dhāraṇī 171r/121r [99]

73. Uṣnị̣̄avijayā-nāma-dhāraṇī 173r/122v [100]

74. Parṇaśavarī-mahāmārīpraśamanī-nāma-dhāraṇī 173v/123r [85]

75. Mārīcī-nāma-dhāraṇī 174v/123v [102]

76. Grahamātṛkā-nāma-dhāraṇī 180v/128r [103]

77. Rāhavyagrahaśānti-upadrava-nāma-dhāraṇī 181v/128v

78. Ketugrahaśānta-nāma-dhāraṇī 183r/130r

79. Daśakrodha-dhāraṇī 183v/130r [114, 128] 
80. Mahāsāhasrapramardanī-nāma-mahāyānasūtra 191v/136r [78]

81. Mahāmāyūrī-vidyārājñī avinașțā yakṣapramukhāt pratilabdhā 204r/145r [79]

82. Mahāśītavatī-nāma-mahāvidyārājñī 205v/146r [80]

83. Mahāpratisarāyāḥ prathamakalpa 210r/148v [76]

84. Mahāpratisarāyā mahāvidyārājñyā rakșāvidhānakalpa 212r/150r [77]

85. Mahārakṣā-mahāmantrānusāriṇi-mahāvidyārāiñī 216v/152v [81]

86. Sarvatathāgatoṣṇiṣasitātapatrā-nāmāparāitā-mahāpratyañgirāmahāvidyārājñ̄i 230r/159v [83]

87. Nārāyaṇaparipṛcchā-mahāmāyāvijayavāhinī-nāma-dhāraṇī 235r/162r [91]

88. Mahāvajravārāhī-nāma-dhāraṇī 236r/162v [105]

89. Sarasvatī-nāma-dhāraṇī 237r/163r [94]

90. Saddharmapāṭha-nāma-dhāraṇī 237v/163v [51, 125]

91. Vajratārā-nāma-dhāraṇī 237v/163v [126]

92. Șaṭpāramitā-nāma-hṛdaya-dhāraṇī 239r/164v [59]

93. Cundā-nāma-dhāraṇī 239r/164v [75, 110]

94. Jambhalendrasya-nāma-dhāraṇī 240r/165r [61]

95. Ugratārā-stotra 241v/165v

96. Mahāmeghanirnādavij̣̣mbhitasuraketu-nāma-dhāraṇī sarvabuddhabhāșita 248r/169v

97. Mahāmeghān mahāyānasūtrād vātamaṇḍalīparivarta-pañcaṣaṣtitama 256v/174r

98. Vairocanīdevī-stava-stotra 256v/174r [96]

99. Dvādaśākșaramūla-nāma-dhāraṇī 257r/174r

100. Cintāmaṇilokeśvara-nāma-dhāraṇī 258r/175r [33, 109]

101. Buddhabhațțārakasya-nāma-dhāraṇī 258v/175r [34, 119]

102. Padmottama-nāma-dhāraṇī 258v/175r

103. Suvarṇaprabhāsottame sūtrendrarāje sarvabuddhabodhisattva-nāma-saṃdhāraṇī 259r/175v [16]

104. Samyaksambuddhavairocanabhāṣita bhagavatyai āryatārādevyā namaskāraikaviṃśati-nāma-stotra 261r/176v

105. Caturbhujamahākāla-sādhana-nāma 261v/177r

106. Kurukullā-nāma-dhārạ̣ī 262r/177r [95] 